\title{
APROXIMACIÓN A LA FIGURA DEL ARQUITECTO SEBASTIÁN DE PORTU (1716-1776)
}

\author{
Myriam Ferreira Fernández \\ Universidad Internacional de La Rioja
}

\begin{abstract}
RESUMEN: Sebastián de Portu fue un arquitecto activo en La Rioja y Álava a mediados del siglo XVIII. Su obra, de la que destacan sus retablos, portadas y otras obras religiosas como cajas de órgano, refleja la evolución del arte desde la fase final del barroco hacia los inicios del rococó. Este artículo ofrece un esbozo para su biografía y una recopilación de su obra artística, con algunas de las características más destacadas de su estilo.
\end{abstract}

Palabras clave: Sebastián de Portu, arte riojano, tardobarroco, rococó, retablos.

\section{AN APPROACH TO THE ARCHITECT SEBASTIÁN DE PORTU (1716-1776)}

ABSTRACT: Sebastián de Portu was an architect who worked in La Rioja and Álava by the middle of the $18^{\text {th }}$ century. His work, from which stand out their altarpieces, front of churches and other religious works as organ cases, reflects the transition from the final phase of the baroque art period to the beginnings of the rococo style. This article offers a sketch for his biography and a compilation of his artistic work, with some of the most significant characteristics of his style.

Keywords: Sebastián de Portu, art from La Rioja, late baroque, rococo, altarpieces.

Sebastián de Portu fue un escultor y retablista activo en La Rioja y Álava a mediados del siglo XVIII. Su figura no era totalmente desconocida, ya que había sido citada abundantemente en publicaciones sobre la historia del arte en La Rioja, en especial las dedicadas al siglo XVIII'. En este artículo trataremos de

1. Mucha de la información sobre este artista había sido dada a conocer por José Manuel Ramírez Martínez, quien había citado obras de Sebastián de Portu en diferentes publicaciones: 
hacer un recorrido ordenado por su biografía y de ofrecer algunos apuntes sobre su estilo artístico.

Sebastián de Portu nació en Navarrete (La Rioja) el 19 de febrero de 1716, hijo de Sebastián de Portu y de María Andresa de Urízar². Su padre era un arquitecto de cierto prestigio, oriundo de Andoain, trasladado a La Rioja por lo menos en 1697, y de quien sabemos que trabajó primero en Calahorra y luego en Logroño, desde donde realizó varias obras en localidades de los alrededores $^{3}$. Posteriormente se instaló en Navarrete, donde falleció el 11 de junio de $1721^{4}$. No hizo testamento, lo cual podría sugerir que su muerte fue repentina e inesperada.

En Navarrete permanecieron viviendo su viuda, María Andresa de Urízar, y tres hijos aún menores de edad: Sebastián (que tenía 5 años cuando falleció su padre), María Josefa y Ángela. La temprana muerte del padre debió ser causa de que la familia viviera algo apurada económicamente, según parece deducirse de un dato recogido por José Manuel Ramírez. El 10 de marzo de 1736, María Andresa vendía a la Cofradía de la Vera Cruz de la iglesia de San Vicente de MuniIla un sagrario que su marido había realizado 30 años antes pero que la iglesia no había adquirido en su momento por discrepancias con el artista. María Andresa logró que finalmente se lo adquirieran y dejó claro que los reales recibidos "son p[ar]a los alim[en]tos precisos míos y de d[ich]os mis hijos menores" ${ }^{\prime \prime}$.

Tal vez por esa situación, Sebastián de Portu hijo, a pesar de ser todavía menor de edad, comenzó muy pronto a trabajar, también como maestro arquitecto. $Y$ eso a pesar de que la temprana muerte de su padre hace imposible que Portu recibiera de él la formación artística. Podemos suponer, por lo tanto, que aprendió el oficio con algunos de los artistas con los que su padre había mantenido relación en vida.

RAMÍREZ MARTíNEZ, J. M., "La Basílica de los Remedios en San Vicente de la Sonsierra (y II)". La Rioja del lunes, 16 de enero de 1989; RAMÍREZ MARTíNEZ, J. M., Guía histórico-artística de Logroño. Logroño, 1994; RAMÍREZ MARTíNEZ, J. M., Retablos mayores de La Rioja. Agoncillo, 1993; RAMÍREZ MARTíNEZ, J. M., La evolución del retablo en La Rioja. Retablos mayores [Archivo digital]. Logroño, 2010. En esta última obra se incluye incluso una aproximación biográfica a Sebastián de Portu, padre e hijo.

2. AP Navarrete, Bautizados 10 (1712-1732), fol 62 v. Era nieto de Sebastián de Portu y Francisca de Goycoechea, de Andoain, y de Pedro de Urízar e Isabel de Forte, de Navarrete.

3. Sebastián de Portu padre realizó la sacristía de Andosilla (1697), las portadas laterales de Santa María de La Redonda (1705) o la torre de la iglesia parroquial de Pedroso (1711) (RAMÍREZ MARTíNEZ, J. M., La evolución del retablo, p. 613). También se le encargó la torre de la iglesia de Alberite (1716), que no llegó a realizar (RUIZ-NAVARRO, J. "La iglesia de Alberite y su retablo mayor". Berceo 81 (1971), pp. 54-55.

4. AP Navarrete, Difuntos 3 (1718-1769), fol. 16 r.

5. AHPLR, Navarrete, Leg. 1553, Mateo Serrano (1736), fols. 48 r.-v. Citado por RAMÍREZ MARTíNEZ, J. M., La evolución del retablo, p. 614. 
En este sentido, tanto por parte de padre como de madre, Portu contaba con parientes que ejercían el oficio de arquitectos. Por parte de padre, Portu estaba emparentado con José Ramírez, quien estaba casado con una hermana de su padre $^{6}$. Y también su madre parece proceder de una conocida familia de artistas, los Urízar: por ejemplo, conocemos a un arquitecto Ilamado Juan Cruz de Urízar que también trabajaba en esta región a mediados del siglo XVIII'. Sin embargo, no hemos encontrado referencias a relaciones entre Portu y los Ramírez o los Urízar. En cambio, con mucha frecuencia le veremos relacionado con otra familia de artistas, los Ortega.

Los Ortega eran una familia de larga tradición artística, probablemente oriundos de Calahorra ${ }^{8}$. Los Portu habían tenido relación con ellos ya en Calahorra: hacia 1699, Sebastián de Portu padre y José de Ortega habían realizado juntos un retablo para la cofradía de la Vera Cruz de Villar de Arnedo. Sin embargo, esta relación tuvo sus altibajos: poco después de terminar el retablo, Portu demandó a Ortega porque no llegaban a un acuerdo sobre cuánto debía cobrar cada uno ${ }^{9}$.

A pesar de este precedente, Sebastián de Portu hijo debió de empezar a relacionarse bastante pronto con los Ortega, en concreto con los dos hijos de José de Ortega: Juan José y Félix. Es posible que Portu aprendiera el oficio con esta familia de artistas. Y es probable que la relación con estos artistas tuviera un carácter no solo profesional, sino también personal, ya que Portu contrajo matrimonio con Catalina de Ortega, natural de Pamplona ${ }^{10}$ y posiblemente emparentada con los Ortega, aunque no sabemos en qué grado ${ }^{11}$.

6. RAMÍREZ MARTÍNEZ, J. M., La evolución del retablo, p. 614.

7. Por ejemplo, fue el encargado de trazar la capilla de Santa Bárbara de Agoncillo, ejecutada por Francisco de Aregita en 1779 (MOYA VALGAÑÓN, J. G. et al., Inventario artístico de Logroño y su provincia. Logroño, 1975, Tomo I, p. 18). En 1771 Juan Cruz de Urízar residía en Logroño, y aparece participando en una protesta firmada por maestros de carpintería por haberse ignorado su hidalguía y haber sido incluidos en las levas militares (AHPLR, Logroño, leg. 1102/1, fols. 100 r.-102 r. Cfr. MARTíNEZ GLERA, E., La arquitectura religiosa barroca en el valle del Iregua. Logroño, 1982).

8. José de Ortega, realizó a principios del siglo XVIII distintos trabajos en Navarra y el País Vasco hasta que en 1732 se trasladó a Briones para realizar la sillería del coro de la iglesia parroquial, donde falleció el 14 de abril de 1732 (AHDL, Briones, Iglesia parroquial de Santa María, Libro $7^{\circ}$ de Fábrica (1725-1748), fol. 107 v.). Sus dos hijos, Félix y Juan José, que habían estado con él trabajando en Briones, se separaron para formar sus propios talleres: Félix se instaló en la zona de Laguardia mientras que Juan José permaneció en Briones.

9. RAMÍREZ MARTÍNEZ, J. M., La evolución del retablo, p. 609.

10. AHDL, Logroño, Iglesia parroquial de Santiago el Real, Libro $4^{\circ}$ de Finados (17721794), fol. $54 \mathrm{v}$.

11. Sabemos que José de Ortega trabajó en Navarra en diversas ocasiones entre 1700 y 1713 , en localidades como Murillo el Cuende, Olite o Sorlada (GARCíA GAíNZA, M. C. et al., Catálogo Monumental de Navarra. Pamplona, 1999, vol. II**, p. 504 y vol. III, 241 y 286), por lo que no sería extraño que hubiera tenido una hija en Pamplona. Sus otros dos hijos también habían nacido en distintas localidades según dónde se encontrara su padre: Félix de Ortega había naci- 
El primer trabajo que tenemos documentado de Sebastián de Portu hijo fueron diversas obras para la iglesia parroquial de San Vicente de la Sonsierra. Los primeros encargos datan de 1737, cuando Portu tenía 21 años. De todos modos, estos encargos eran obras de escasa envergadura: realizar unos cajones para la sacristía por 750 reales; poner marcos a cinco sacras, hacer una puerta para el trascoro y otra para las capillas, componer los confesonarios... Además, la consideración que Portu recibía ni siquiera era la de arquitecto: de hecho, cuando en los Libros de Fábrica se le van anotando los pagos, se le denomina "maestro carpintero $^{\prime \prime 2}$.

Probablemente, su propia juventud supuso un inconveniente al tratar de conseguir encargos. En 1740 se presentó al remate de un retablo para la ermita del Santo Cristo de Fuenmayor, adjudicándosele la ejecución de la obra por 7550 reales. Sin embargo, el Provisor, preocupado por la juventud de Portu, indicó a la iglesia que anulara ese remate y se encargara la obra a un artista ya consolidado, de modo que el encargo pasó a Santiago del Amo, por un precio ligeramente superior, 7.600 reales $^{13}$.

En torno a 1742, Portu recibió un encargo de mayor envergadura: las obras del pórtico de entrada en la iglesia parroquial de San Vicente de la Sonsierra, cuyo precio total se estipuló en 10.900 reales $^{14}$. Se trata de un cuerpo que se superpone a la entrada gótica de la iglesia, estructurado como un arco triunfal, con un arco de medio punto encuadrado por dos pilastras y coronado por una hornacina en la que se encuentra una imagen de la Inmaculada Concepción. La decoración, minuciosa y basada sobre todo en motivos vegetales, la sitúa en un estilo tardobarroco. Es una de las pocas obras de cantería que realizó Portu, quien pronto se orientó más hacia la talla en madera.

Hacia 1746, se le encargó el retablo colateral de Nuestra Señora del Rosario de San Torcuato (La Rioja) ${ }^{15}$, según las trazas que él mismo había diseñado. Este encargo supuso un enfrentamiento con uno de los Ortega. En efecto, Juan José de Ortega interpuso pleito, ya que el contrato se había hecho de forma directa, a pesar de que era obligatorio sacar la obra a remate. Finalmente, el sacerdote de la parroquia de San Torcuato ganó el pleito sin convocar el remate porque la obra la había encargado él personalmente y no la parroquia ${ }^{16}$.

\footnotetext{
do en Orés (Aragón) y Juan José de Ortega en Calahorra (Cfr. DíAZ, P., "Juan José de Ortega y el retablo mayor de la ermita de San Juan". La voz amiga de Amigos de Briones 13 (2006), 21).

12. AHDL, San Vicente de la Sonsierra, Fábrica (1736-1751), fol. 73 v., 93 r. y 98 r.

13. RAMÍREZ MARTÍNEZ, J. M., La evolución del retablo, p. 565.

14. AHDL, San Vicente de la Sonsierra, Fábrica (1736-1751), fol. 206 r. y v., 206 v., 221 r. y v., 222 v., 233 r.-234 r. y 250 r.

15. RAMÍREZ MARTÍNEZ, J. M., Retablos mayores, pp. 103-104.

16. RAMÍREZ MARTÍNEZ, J. M., La evolución del retablo, p. 614.
} 
Hacia 1748 Portu fue abandonando los encargos de La Rioja Alta, dirigiéndose más hacia localidades de La Rioja Central, en torno a Logroño. En 1748 realizó un retablo en la iglesia parroquial de Santa María de Agoncillo, dedicado a Cristo Crucificado ${ }^{17}$.

El 3 de mayo de 1751 aparece como vecino de Entrena, localidad en la que diseñó un cancel para la iglesia parroquial, así como los confesonarios y dos hacheros en triángulo que, según la escritura, debían ser como los del Convento de la Merced de Logroño. Además, aunque no asumió personalmente la ejecución de la obra, actuó como fiador del artífice que ganó el remate para la ejecución, Diego Bastida ${ }^{18}$.

Es posible que fuera por esas mismas fechas cuando realizó la traza, diseño y nivelación para la fuente de la plaza, también en Entrena, asistiendo personalmente a los trabajos de su construcción. Sin embargo, en 1766 se quejaba de que todavía no le habían terminado de pagar las cantidades acordadas ${ }^{19}$.

Hacia 1752, según Ramírez, Sebastián de Portu regresó a San Vicente de la Sonsierra, en esta ocasión para trabajar en una obra destacada: el retablo mayor de la Basílica de los Remedios de San Vicente de la Sonsierra ${ }^{20}$, donde probablemente coincidió trabajando con Félix de Ortega ${ }^{21}$.

En 1752 Portu se instaló en Logroño y comenzó a realizar obras en esta localidad. El primer encargo que conocemos son las trazas de los retablos colaterales de Santa María de Palacio en Logroño (Fig. 1). Esta traza la ejecutaría en compañía de un conocido arquitecto de Logroño, José Calvo. Sin embargo, la ejecución final del retablo corrió a cargo de dos arquitectos de Tudela, Antonio y José del Río. Los retablos estaban originalmente dedicados a San Jerónimo y los Reyes, aunque hoy acogen a San Judas y San Nicolás de Bari ${ }^{22}$.

Hacia 1752 recibió un encargo más importante: la construcción del retablo mayor de San Bartolomé de Logroño (Fig. 2). Uno de los sacerdotes de esta iglesia, Juan de Lejarzu, deseaba construir un nuevo retablo mayor, ya que el existente se encontraba en muy malas condiciones. Lejarzu decidió pagar él mismo

17. MOYA VALGAÑÓN, J. G. et al., Inventario artístico, tomo I, p. 18.

18. AHPLR, Protocolos notariales, Manuel de Sol Revilla, leg. 1290, año 1751, fols. 126 r.132 r. A pesar de este documento, Sebastián no figura como vecino de Entrena en el Catastro de Ensenada que se realizó pocos meses después, ni tampoco aparece residiendo en ninguna otra localidad riojana.

19. AHPLR, Logroño, leg. 1085/2, fol. 22 r. y v.

20. Según Ramírez estaba trabajando "por encargo expreso de don Félix de Davalillo y la Piscina, Director General de las Rentas del Tabaco" (RAMÍREZ MARTíNEZ, J. M., "La Basílica de los Remedios").

21. DÍAZ, P., Juan José de Ortega, p. 21.

22. MOYA VALGAÑÓN, J. G. et al., Inventario artístico, tomo II, p. 313; RAMÍREZ MARTíNEZ, J. M., Guía histórico-artística de Logroño, pp. 217-219. 


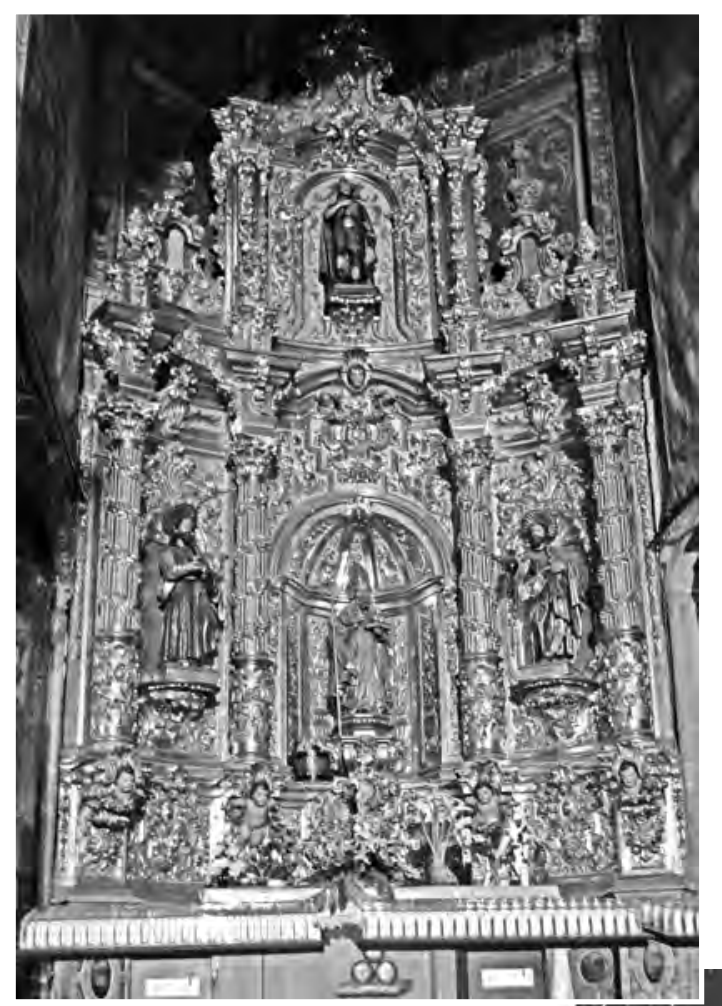

Figura 1. Retablo de San Nicolás

(Santa María de Palacio, Logroño).

Figura 2. Retablo mayor

(San Bartolomé, Logroño).

Fotografía cedida por don Vicente del Río.

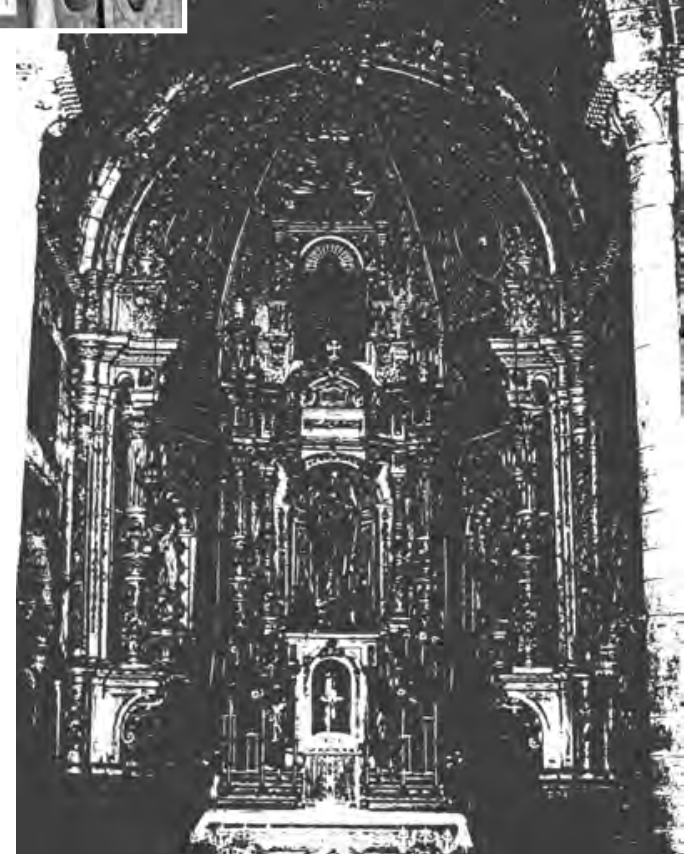


el retablo, y con el privilegio que le daba esa decisión para organizar las cosas a su manera, buscó un maestro que lo pudiese construir para encargárselo directamente. Según se indica en la escritura de contratación, tras haber "practicado las más exquisitas diligencias en busca de maestros que lo ejecutasen con toda perfección y primor y al menor coste", decidió encargarle este trabajo a Sebastián de Portu, siguiendo traza de José Calvo, con quien acababa de colaborar en Santa María de Palacio ${ }^{23}$.

Además de la realización del retablo, Lejarzu encargó a Portu los relieves del conjunto: dos escenas (el prendimiento y el martirio de san Bartolomé) en los netos del pedestal, y cuatro imágenes dibujadas en el sotabanco: San Pedro, San Felipe Neri, San Francisco de Sales y San Carlos Borromeo. En cambio, las imágenes de bulto redondo serían realizadas por Calvo y debían representar a San Bartolomé, la Asunción de Nuestra Señora, San Joaquín y Santa Ana. Este reparto ya nos indica que la actividad de Portu se dirigió más hacia la retablística que hacia la escultura propiamente dicha.

La construcción había sido prevista para un año, pero en 1757 todavía no estaba terminada. Por lo que parece, Lejarzu se había ofrecido a pagar la obra con entusiasmo, pero cuando la tuvo en marcha hizo lo posible por reducir costes, lo cual ocasionó bastantes tensiones. Empezó por poner condiciones en el contrato para evitar posibles aumentos de precio, indicando que "si por devoción o por cualquiera otro título o motivo hubiese mejoras algunas en el retablo no se ha de poder pedir ni se ha de pagar el importe de ellas". Luego, fue descontando dinero a los artistas por no cumplir exactamente las condiciones: así, a Portu, por no hacer unos angelitos para la imagen de la Asunción, le descontó 200 reales. Y, además, fue retrasándose en los pagos que debía hacer, hasta el punto de que hacia 1757 el obispo de Calahorra, en su visita a la iglesia, tuvo que intervenir para que se pagaran a José Calvo y a Sebastián de Portu 260 y 2000 reales respectivamente por su trabajo en el retablo mayor. Los 260 reales de Calvo se le debían tanto por la traza, que aún no se le había terminado de pagar, como por el reconocimiento del retablo, que había llevado a cabo él mismo ${ }^{24}$.

De todo este conjunto no nos ha quedado nada porque el retablo fue desmontado en los años 50 del siglo XX debido a su mal estado de conservación.

Hacia 1753 a Sebastián se le encargaron cuatro retablos colaterales para la localidad alavesa de Labastida, cuya construcción se prolongaría hasta 1757 . Se encuentran ubicados en los muros de los contrafuertes posteriores y están dedi-

23. AHPLR, Logroño, Manuel de Arteaga, leg. 1081, fols. 53 r.-54 v. Sobre este retablo, ver RUGO DE SEYA, Las parroquias de Logroño. Acedo, 1989 (edición facsímil del original de 1941), pp. 91 y 97; RUIZ DE GALARRETA, J. M. y ALCOLEA, S., Logroño y su provincia, Barcelona, 1962, p. 24; RAMÍREZ MARTÍNEZ, J. M., Guía histórico-artística de Logroño, p. 262.

24. AHDL, Logroño, San Bartolomé, Libro de Fábrica (1636-1783), fol. 251 v.-263 v. 
cados a San Pedro, Nuestra Señora del Rosario, San Sebastián y el Santo Cristo de los Remedios ${ }^{25}$.

En el proceso de realización de estos retablos, Portu coincidió con otro artista que también tiene cierto protagonismo en su biografía: fray José de San Juan de la Cruz, que fue quien realizó el reconocimiento de los retablos.

Fray José era un lego carmelita con una intensa actividad como arquitecto en Logroño y sus alrededores. El hecho de que fuera un religioso facilitó que recibiera numerosos encargos por parte de órdenes religiosas, incluidas algunas obras en su propio convento de Logroño. La reputación que adquirió por esas obras, junto con su carácter, seguro y decidido, y su facilidad para apoyarse en teóricos de la arquitectura, como Tosca o Vitruvio, difundieron su prestigio como arquitecto, lo cual hizo que su labor se extendiera por gran parte de Navarra, Álava y Burgos. No sabemos si Portu conoció en esta ocasión a fray José o le conocía previamente, ya que éste mantenía un contacto habitual con los Ortega ${ }^{26}$. De hecho, su hermano pequeño, Manuel de Ágreda, se casaría años después con una hija de Félix de Ortega.

Todas las obras de Sebastián de Portu citadas hasta este momento se encuadran en la fase final del retablo barroco. En esta fase, el barroco de principios del siglo XVIII, más solemne y caracterizado por el uso de columnas salomónicas y decoración de racimos y uvas es sustituido por un estilo nervioso y movido, donde los planos del retablo y la decoración parecen fragmentarse y romperse. La planta de estos retablos será, por lo tanto, muy movida, quebrada, y la decoración será muy abundante pero de pequeñas dimensiones. Las columnas salomónicas dejan paso a balaustres, estípites y columnas bulbosas, y los motivos ornamentales más abundantes serán motivos florales y vegetales, guirnaldas, puntas de diamante o querubines. Además, los retablos de cascarón irán dejando paso a unos retablos de forma triangular, con cuerpo rectangular, ático flanqueado por aletones y un remate aflechado en la parte superior, que dota al conjunto de una gran ascensionalidad ${ }^{27}$.

Estas características están presentes en los retablos que hemos citado hasta el momento. Portu utilizará la estructura triangular en los retablos de San Torcuato, en los retablos colaterales de Santa María de Palacio de Logroño y en los retablos de Labastida. Estos retablos tienen también en común los soportes diná-

25. ENCISO VIANA, E. y CANTERA ORIVE, J., Catálogo Monumental. Diócesis de Vitoria. Rioja Alavesa. Vitoria, 1967, p. 215. Cfr. RAMÍREZ MARTíNEZ, J. M., La evolución del retablo, p. 615.

26. José de Ortega y fray José de San Juan de la Cruz habían coincidido trabajando en la basílica de San Gregorio Ostiense de Sorlada hacia 1713 (GARCÍA GAÍNZA, M. C. et al., Catálogo Monumental, vol. II**, p. 504 y vol. III, 241 y 286).

27. Sobre el estilo tardobarroco en esta zona, cfr. VÉLEZ CHAURRI, J. J., El retablo barroco en los límites de las provincias de Álava, Burgos y La Rioja: 1600-1780. Vitoria, 1990, pp. 173-177. 
micos, los motivos florales como decoración, el gran número y minuciosidad de los elementos ornamentales y las hornacinas aveneradas para albergar las imágenes. Sin embargo, hay diferencias entre unos y otros. El retablo de San Torcuato es el más clásico: resulta el más horizontal y estable, usa como soporte columnas corintias estriadas aunque con apliques en el fuste y se remata con un frontón curvo roto. Los retablos de Logroño son más dinámicos: las calles laterales son más estrechas y menos profundas, las columnas son complejas, ya que tienen el tercio inferior decorado con querubines y el superior estriado con guirnaldas helicoidales de flores, los aletones del ático se sustituyen por espejos ovalados enmarcados en cornucopias que, junto con el remate flordelisado de la parte superior, acentúan la verticalidad del conjunto. En Labastida también hay una gran ascensionalidad, ya que no hay esculturas en las calles laterales del cuerpo, el ático es muy alto y estrecho y el remate, enmarcado por un frontón curvo roto pero de menores dimensiones que en San Torcuato, presenta una gran elevación. En este caso, sorprende por la gran carga decorativa a pesar de ser un conjunto de pequeñas dimensiones: las columnas son bulbosas, con una gran carnosidad, y en el ático hay dobles columnas a los lados de la hornacina central, también con fuste bulboso pero diversas entre sí.

En Logroño hay dos elementos que estarán presentes en otras obras posteriores: las columnas del cuerpo coronadas con un cimacio con entablamento volado (que en cierta manera está también presente en Labastida) y el entablamento del cuerpo dibujando en el centro un arco rebajado, en este caso con un querubín en la clave.

El retablo mayor de San Bartolomé es un caso aparte porque no fue diseñado por Sebastián de Portu sino por José Calvo. Aun así, es indudable que la realización del mismo influyó en Portu, y será el modelo que siga en gran medida en el otro retablo mayor que tendrá que realizar años después: el de Pipaón.

El retablo mayor de San Bartolomé era un retablo semicircular de forma cóncava, muy profundo, compuesto por banco, cuerpo de tres calles y ático. Del banco, apoyadas en ménsulas, surgen cuatro grandes columnas abalaustradas entre las que se sitúan las tres hornacinas del cuerpo, aveneradas. La principal tiene forma de baldaquino, con remate en templete. El ático se divide en tres partes por medio de nervios: en los laterales hay medallones con figuras en relieve y, en el centro, una hornacina avenerada coronada por el Espíritu Santo entre rayos. La decoración es muy abundante en las columnas, dinteles, frisos, ménsulas, etc. y especialmente en el ático, que está recubierto por una decoración minuciosa y nerviosa que cubre toda su superficie. Los motivos ornamentales más usados son flores, vegetación, jarrones e incluso rostros fantásticos que recuerdan máscaras chinescas con forma de animales salvajes.

Hacia 1755, el estilo de Sebastián de Portu empieza a evolucionar hacia el rococó. En ese año, cuando aún no había terminado ni el retablo de San Bartolomé ni los retablos de Labastida, recibió otro encargo: el sagrario del retablo 
de San Miguel de la iglesia parroquial de Murillo de Río Leza ${ }^{28}$. Y solo un año después, el 29 de diciembre de 1756 contrataba la realización de dos colaterales de nueva planta según su propia traza y condiciones, nuevamente en San Vicente de la Sonsierra. El precio acordado eran 22.000 reales de vellón y el plazo previsto para que los retablos estuvieran terminados era de dos años, antes del 29 de diciembre de 1758. Además, se le encargaban también otras obras como una mesa de altar para la sacristía y su retablo, la colocación de la historia de la Coronación de Espinas en el retablo de San Ramón, hacer la caja de San Ramón semejante a la del Santo Cristo y otras obras ${ }^{29}$.

Estos encargos suponen además un cambio en la consideración de la iglesia de San Vicente de la Sonsierra hacia él. Si en sus primeras obras era citado como un "maestro carpintero", con estos retablos por fin recibe la consideración de "maestro arquitecto". Pero este cambio en la nomenclatura no significaba que tuviese habitualmente una consideración especial por su trabajo como artista. Así que Portu buscó otra forma de lograr que se le reconocieran ciertos privilegios por su labor como arquitecto. Y, como en Logroño no existía un gremio que defendiera los derechos de los artistas, Portu solicitó la protección de la Cofradía de San Lucas de Valladolid, una agrupación de artistas que tenía el privilegio de que a todos sus miembros se les reconocían "todos los honores, exenciones y regalías de que deben gozar los que ejercen el noble arte de la Arquitectura" ${ }^{\prime 30}$.

Puede que Portu conociera esta cofradía por medio de José Bejés, quien unos años antes también había solicitado la admisión en esa misma institución ${ }^{31}$. José Bejés era un pintor y dorador, oriundo de Potes (Santander), quien tras formarse en Italia y otros países europeos, regresó a España y acabó por instalarse en Logroño, donde casó dos veces y donde falleció en 1785. El prestigio de su formación, su carácter cosmopolita y su pintura vibrante y colorista le atrajeron una gran cantidad de discípulos haciendo que su estilo fuera el más difundido en La Rioja a mediados del siglo XVIII ${ }^{32}$. Es lógico, por lo tanto, que tuviera un gran interés en que sus privilegios como artista le fueran reconocidos.

28. Ramírez martíneZ, J. M., Guía Histórico-Artística. Murillo de Río Leza. Logroño, 1992, p. 51.

29. AHPLR, Protocolos notariales, San Vicente de la Sonsierra, Manuel Gil Martínez Manso, leg. 4114, año 1756, fols. 29 r.-30 v. y AHDL, San Vicente de la Sonsierra, Fábrica (17521776), fol. 48 v., 49 r., 62 v. y 86 v. Cfr. RAMÍREZ MARTíNEZ, J. M., Retablos mayores, p. 104.

30. AHPLR, Protocolos notariales, Logroño, Antonio Gómez Samaniego, leg. 1092, año 1759, fols. 98 r.-101 v. La Cofradía estaba "sita en el Colegio de Niñas Huerfanas de la citada ciudad de Valladolid que se compone de maestros escultores, ensambladores y otros ejercicios liberales y artes inferiores". Sobre esta cofradía, cfr. AA.VV., Valladolid en el siglo XVIII. Valladolid, 1984, p. 222 y 354.

31. AHPLR, Logroño, Manuel Rodríguez, leg. 1684, año 1756, fol. 88 r. y v.; AHPLR, Logroño, Manuel Rodríguez, leg. 1684, año 1757, fol. 22 r. y v.

32. Sobre Bejés, cfr. CEÁN BERMÚDEZ, J. A., Diccionario histórico de los más ilustres profesores de las Bellas Artes en España, Madrid, 2001, p. 212; TORRALBA SORIANO, F., "José 
No sabemos en qué momento se conocieron Portu y Bejés, aunque no debió de ser difícil ya que ambos trabajaban en un ámbito similar en una ciudad pequeña. Además, tenían obras comunes, ya que Bejés había policromado los retablos de Santa María de Palacio que Portu había trazado pocos años antes.

La instancia para ser admitido en la cofradía de San Lucas de Valladolid tiene fecha de 17 de diciembre de $1759^{33}$. Portu la envío con otros tres arquitectos más jóvenes: dos hijos de Félix de Ortega, Manuel y Ángel, y un yerno de Félix, Manuel de Ágreda, quien, como ya hemos dicho, era además hermano de fray José de San Juan de la Cruz. De hecho, el propio fray José aparece como uno de los testigos que certifican la labor de estos tres arquitectos. En la escritura, se indica también que han desempeñado muchos trabajos en Logroño y sus alrededores, tanto solos como en grupo, lo cual nos confirma que los Ortega y Portu mantenían una relación artística que les Ilevaba a cooperar entre sí.

Otro fruto de esta relación fue la realización del retablo colateral del Santo Cristo en la localidad de San Asensio, que se le encargó a Portu también en 1759. En este caso, la traza del retablo había sido realizada por Fray José de San Juan de la Cruz, y como fiador de Portu aparecía Manuel de Ortega, uno de los que solicitaban la admisión en la cofradía con él. El retablo debía sustituir el existente de San Andrés y era responsabilidad de Portu el quitar el retablo antiguo y trasladar y colocar el retablo nuevo. En otro sentido, es también interesante constatar cómo sus intentos por lograr cierta consideración social iban dando resultado: en la escritura se le aplica el título de "don" ${ }^{34}$.

Su relación con los Ortega quedó nuevamente de manifiesto cuando en 1764 falleció en Briones Juan José de Ortega ${ }^{35}$. Su esposa acababa de morir pocos meses antes, por lo que los dos hijos del matrimonio quedaron bajo la custodia

Bexes y los decoradores barrocos españoles". Berceo 34 (1955), pp. 57-78; GUTIÉRREZ PASTOR, I., "La colección de pinturas del monasterio de San Millán de la Cogolla". Cuadernos de investigación: Historia 10 (1984), pp. 129-148.

33. AHPLR, Protocolos notariales, Logroño, Antonio Gómez Samaniego, leg. 1092, año 1759 , fols. 98 r. -101 v.

34. AHPLR, San Asensio, Bernardo José de Puebla Aranguren, leg. 4142 (1758), fols. 158 r. y v. Se adjuntaba la fianza firmada en Logroño a 19 de abril de 1759, donde aparecían citados los testigos, Santiago de Aguirre, Manuel de Zalavardo y Manuel Ortega. Esta escritura resulta muy interesante, como ya puso de manifiesto José Manuel Ramírez, por la disertación que realiza Fray José de San Juan de la Cruz en las condiciones sobre los tratadistas de arquitectura clásico y la influencia que deben tener en el diseño de las obras (Cfr. RAMÍREZ MARTínEZ, J. M., Retablos mayores, p. 106, nota 33).

35. AHDL, Briones, Iglesia parroquial de Santa María, Libro 5o de Finados (1745-1784), fol. $167 \mathrm{~V}$. 
de un destacado vecino, Domingo de Negueruela. Portu, por su parte, se ofreció como fiador del tutor ${ }^{36}$.

Otro detalle donde también se ve a Portu ofreciéndose como valedor de otra persona tuvo como protagonista a Francisco de la Campra, quien había sido uno de sus fiadores en la contratación del retablo de San Bartolomé de Logroño. En 1764, Campra estaba en la Cárcel Real de Logroño por deudas pero, debido a su avanzada edad y a que padecía gota, solicitó que se le dejara en libertad. Medardo Raimel y don Juan d'Elhuyar, médico y cirujano titulares de la ciudad, fueron a examinarle a la cárcel y aseguraron que era muy difícil que curara allí. Así que Sebastián se presentó ante las autoridades y se ofreció a pagar la fianza por Campra para que éste saliera de la cárcel, lo cual se autorizón ${ }^{37}$.

Siguiendo con las obras que Portu realizó, en 1766 se le encargó en

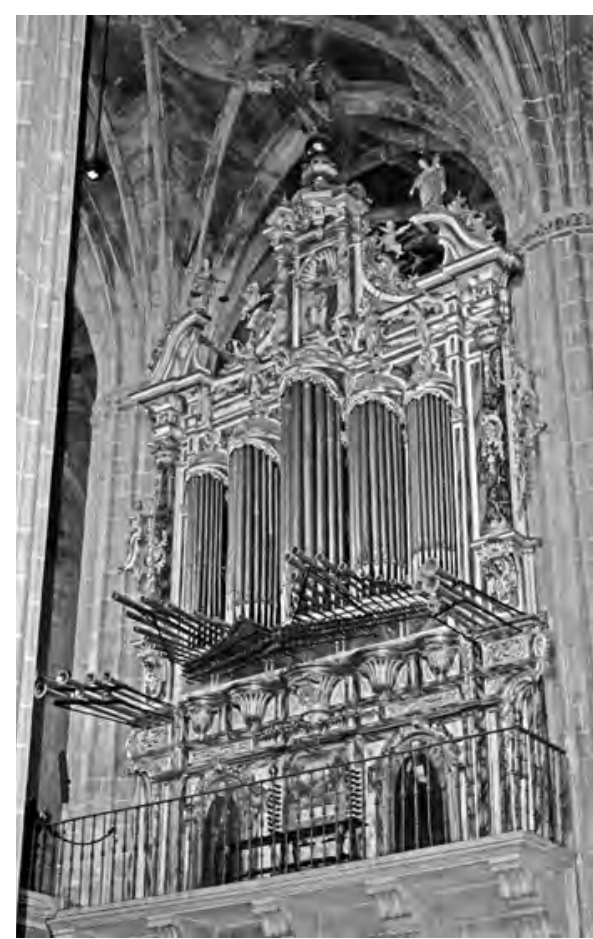

Figura 3. Órgano (Santa María, Briones). Briones la construcción de la caja del órgano para la iglesia parroquial de esta localidad (Fig. 3). Se trató de una obra destacada, ya que los responsables de la fábrica de Briones querían realizar un órgano magnífico y de primera calidad. Por eso, encargaron la construcción del órgano a un organero italiano, Andrés Gasparini, y la caja del mismo a Sebastián de Portu. Portu tenía un plazo de 3 meses para realizar la obra y recibiría un total de 600 ducados de vellón ${ }^{38}$.

La elección de estos dos maestros, que parecía ser muy pensada, trajo grandes problemas ${ }^{39}$. Gasparini se reveló como un personaje complicado, que hacía grandes exigencias y solicitaba dinero constantemente (hasta a Portu llegó a

36. AHPLR, Protocolos notariales, Briones, Pedro Antonio Rubio Olarte, leg. 4151 (17621766), fol.102 r.

37. AHPLR, Francisco Lucas de Echeverría, Protocolos Notariales, leg. 1100/1 (1764), fols. 57 r.-58 r. Sobre Francisco de la Campra, cfr. AHPLR, Catastro de Ensenada, Logroño, Memoriales de seglares, vol. 0402, no 361-362.

38. AHDL, Briones, Iglesia parroquial de Santa María, Libro 9o de Fábrica (1755-1771), fol. 313 v. $-354 \mathrm{r}$.

39. Se conoce bastante bien el proceso de construcción de este órgano, tanto gracias a la documentación ofertada por el Libro de fábrica como por publicaciones sobre el tema, por 
deberle 300 reales que finalmente tuvo que pagar la propia Iglesia). A finales de 1766, cuando la caja estaba bastante avanzada, Gasparini escribió un memorial en el que indicaba que la caja no se estaba construyendo con la suficiente seguridad y que no aguantaría cuando se colocaron los caños sobre ella. Los miembros del cabildo de la iglesia se asustaron y decidieron llamar a otros maestros que reconocieran si eso era cierto. En julio de 1767 Ilegaron dos maestros arquitectos que revisaron la caja del órgano, asegurando que era lo suficientemente segura y propusieron que se le diera a Portu una gratificación de 500 reales por las mejoras que había realizado ${ }^{40}$. Finalmente, Gasparini recibió el encargo de construir el órgano de la Basílica de Santa María de la Vega en Haro y marchó allí... ante las protestas del cabildo de Briones porque no había terminado el órgano antes de irse.

Portu realizó su obra con menos problemas, aunque también hubo un momento de tensión cuando dijo que la nueva caja no iba a caber en el sitio de la antigua y que si querían que la colocara ahí tenían que darle 600 reales más por el trabajo. El cabildo se resistió y finalmente ofreció 400 reales, a los que Portu se avino.

El libro de fábrica recoge las fases del trabajo y los distintos pagos que se fueron haciendo a Portu y sus ayudantes, de los que se cita específicamente a su criado Tomás de Santander ${ }^{41}$. Además, también se indica que aprovechando la presencia de Portu se le fueron pidiendo otros trabajos como componer los dos colaterales de la sacristía. Un encargo sorprendente, porque solo cobró 16 reales por ello ${ }^{42}$, lo cual recuerda las obras que, como carpintero le encargaban en San Vicente de la Sonsierra en su juventud.

Tal vez la disponibilidad de Portu para aceptar unos encargos tan pequeños estuviera evidenciando que, a pesar de la gran cantidad de encargos recibidos, su situación económica seguía sin ser buena. A este respecto, en 1765 vendía, junto con su mujer, algunas propiedades que tenía en San Vicente de la Sonsierra desde 1751, lo cual puede indicar que tenían necesidad de dinero ${ }^{43}$.

ejemplo GÓMEZ, Á. et al., Órgano de la parroquia de Santa María de Briones. Logroño, 1994.

40. No sabemos si tendrá relación, pero uno de los maestros que reconocieron la obra, Santiago de Herdoiza, tenía razones para albergar cierto resentimiento contra Gasparini. De hecho, dos años antes, Gasparini se había opuesto a que Herdoiza reconociese el órgano que acababa de construir en Santo Domingo de la Calzada, a pesar de que había sido propuesto por los responsables de la parroquia (cfr. CAMPO OLASO, J. S., El órgano de la villa de Ochandiano. Donostia, 2000, pp. 104-105), en http://www.euskomedia.org/PDFAnlt/lankidetzan/16/16001252.pdf.

41. Tomás de Santander recibió 75 reales por haber trabajado doce días en el órgano (AHDL, Briones, Iglesia parroquial de Santa María, Libro 9o de Fábrica (1755-1771), fol. 354 r).

42. AHDL, Briones, Iglesia parroquial de Santa María, Libro 9o de Fábrica (1755-1771), fol $349 \mathrm{r}$.

43. AHPLR, Protocolos notariales, Manuel Rodríguez, leg. 1684, año 1765, fol. 107. 
En 1768 se le encargó el retablo de Nuestra Señora del Rosario en Azofra realizado por 100 ducados. Además, se piensa que al año siguiente (1769) realizó unos reparos en el retablo mayor de Azofra ${ }^{44}$.

Estas obras de San Vicente de la Sonsierra, Briones y Azofra se encuadran ya en el estilo rococó, como se aprecia en la sustitución de la mayoría de los motivos ornamentales por rocalla. Así vemos cómo la rocalla se usa como elemento decorativo en los fustes de las columnas, en los netos del banco y en el remate de los arcos de las hornacinas. Sin embargo, algunos elementos de los retablos anteriores siguen permaneciendo: en los retablos de San Vicente aún se usan las columnas bulbosas en el ático, se mantiene la misma tendencia a la ascensionalidad y se van repitiendo algunos detalles: así, las columnas con cimacios volados que habíamos visto en Logroño están también presentes en san Vicente de la Sonsierra y el remate curvilíneo enmarcado por un frontón curvo roto del órgano de Briones es muy similar al de los retablos de Labastida.

En 1769 tuvo lugar un suceso conocido gracias al artículo sobre el tema que publicaron René Payo y José Matesanz ${ }^{45}$. El pintor José Bejés, ya citado, envió un memorial a la Real Academia de Bellas Artes de San Fernando solicitando que se vetara a Fray José de San Juan de la Cruz la realización de obras de arte, argumentando que sus obras eran poco seguras y de escaso gusto estético. Sebastián de Portu firmó el memorial apoyando la solicitud de Bejés.

Que Bejés, hombre de genio vivo, entablara una disputa con fray José, no resulta extraño, y más cuando el memorial pone de manifiesto que había habido roces entre ellos sobre la adjudicación de algunas obras. Pero es más extraño que Portu se ponga del lado de Bejés, cuando siempre había mantenido buenas relaciones con fray José: habían colaborado en las obras realizadas en Labastida o San Asensio, y fray José había apoyado a Portu en su solicitud de ingreso en la Cofradía de San Lucas de Valladolid. El memorial no deja intuir las razones que le movieron: se aprecia que la redacción se debe fundamentalmente a Bejés y que el papel de Portu en la querella es secundario. Es posible que tuviera lugar algún suceso que desconocemos y que supusiera el enfrentamiento entre ambos artistas.

Lo interesante del tema es que Bejés y Portu acuden a la autoridad de la Academia para desprestigiar a fray José, y además lo hacen criticando el estilo de éste por no ajustarse a un estilo académico. En este sentido, se ve que en ambos artistas hay una intención de adecuarse a las nuevas corrientes que procedían de la Corte, mientras que fray José sigue una línea más tradicional.

44. RAMÍREZ MARTÍNEZ, J. M., Retablos mayores, p. 262.

45. PAYO, R. J. y MATESANZ DEL BARRIO, J., "Una polémica artística en el entorno de la Academia de Bellas Artes de San Fernando. Fray José de San Juan de la Cruz y José Bejes. Entre el Barroco Castizo y el Barroco Cortesano". De arte 10 (2011), pp. 129-156. 
Poco después de este suceso, en 1770, Sebastián contrató una nueva obra, en la que precisamente parece poner en práctica esa orientación academicista. Se trata del retablo mayor de Pipaón, una localidad alavesa para la que también realizó dos retablos colaterales y un tornavoz ${ }^{46}$. Como hemos dicho, su estructura es similar al retablo mayor de San Bartolomé: un retablo en cascarón, con forma cóncava y ático dividido en tres por nervios. Sin embargo, el retablo de Pipaón es mucho más simple y desnudo: el templete central es sustituido por un sencillo cuadro y, lo más Ilamativo, los elementos decorativos se reducen drásticamente. En efecto, las columnas del retablo son de orden corintio con fuste estriado, sin ningún tipo de decoración en el fuste y la rocalla, aunque aún presente en el banco y el ático, es menos abundante en torno a las hornacinas. Estas características, unidas a la policromía, ya de tipo neoclásico, ponen esta obra en relación con los retablos impulsados desde la Real Academia de Bellas Artes de San Fernando.

Es probable que este conjunto de Pipaón fuera la última obra realizada por Portu. Poco después de realizarla, el 13 de marzo 1776, falleció en Logroño, a los 60 años de edad ${ }^{47}$. Solo tres semanas, el 6 de abril de 1776, después fallecía también su mujer, Catalina Ortega ${ }^{48}$. En la partida no se indica que hubieran tenido hijos, pero sí se deja constancia de que ninguno de los dos hizo testamento por su pobreza.

Un final triste que evidencia la situación de los artistas a mediados del siglo XVIII: una época en la que los artistas competían entre sí para adjudicarse la construcción de retablos, en la que tan pronto se unían para lograr encargos comunes como se acusaban ante instancias superiores para desprestigiar al competidor, en la que asumían más obras de las que podían realizar y ni siquiera así lograban, en ocasiones, salir de la pobreza. En este panorama, la figura de Sebastián de Portu aparece consolidada por su capacidad de trabajo, su disponibilidad para aceptar cualquier tipo de obras, su facilidad para asociarse con artistas prestigiosos de la época y su sensibilidad a los cambios de estilo e influencias que se iban extendiendo en esos momentos. Tal vez por todo ello, aunque aún no experimentó plenamente el aumento de consideración que los artistas irían alcanzando en el siglo XVIII, sí que alcanzó un prestigio mayor que otros artistas contemporáneos.

46. PORTILLA VITORIA, M. y EGUÍA LÓPEZ DE SABANDO, J., Catálogo Monumental. Diócesis de Vitoria. Arciprestazgos de Treviño, Albaina y Campezo. Vitoria, 1965, p. 305-307. Cfr. RAMÍREZ MARTÍNEZ, J. M., La evolución del retablo, p. 615.

47. AHDL, Logroño, Iglesia parroquial de Santiago el Real, Libro $4^{\circ}$ de Finados (17721794), fol. $54 \mathrm{v}$.

48. AHDL, Logroño, Iglesia parroquial de Santiago el Real, Libro $4^{\circ}$ de Finados (17721794), fol. 55 r. 